\title{
RESULTS OF MODIFICATION OF CAST IRON BY CARBON NANOSTRUCTURES OF GAS CLEANING DUST OF SILICON PRODUCTION
}

\author{
A.I. Karlina \\ Innovative technologies \\ National Research Irkutsk Technical University \\ Irkutsk, Russia \\ karlinat@mail.ru \\ V.V. Kondratiev \\ Innovative technologies \\ National Research Irkutsk Technical University \\ Irkutsk, Russia \\ kvv@istu.edu
}

\author{
A.E. Balanovsky \\ Machine-Building Technologies and Materials \\ National Research Irkutsk Technical University \\ Irkutsk, Russia \\ fuco.64@mail.ru
}

A.D. Kolosov

Innovative technologies

National Research Irkutsk Technical University

Irkutsk, Russia

kolosovad@ex.istu.edu

\author{
N.N. Ivanchik \\ Innovative technologies \\ National Research Irkutsk Technical University \\ Irkutsk, Russia \\ inn@ex.istu.edu
}

\begin{abstract}
A series of experiments for the melting of cast iron GI15, according to the sandwich-type scheme of the process with a modifier (composition 1, 2, 3) did not reveal any significant differences in the mechanical properties of the modified samples, depending on the mode of administration. Surface examination of the samples with the help of scanning electron microscopy showed significant differences in the structure of the metal surface. All the materials studied have the structure of gray iron on a ferrite-pearlitic basis with graphite of a laminar rectilinear form of the type PGf1, in unmodified samples. Modified samples have the form of inclusions of graphite of the type PGf4 nestshaped, vortical shape. The conducted studies of microstructures after mechanical tests of samples of cast iron GI30, modified with composition 2, showed the presence of inclusions of globular graphite. The introduction of small amounts of a modifier with nano-sized structures during the teeming leads to: an increase in the content of perlite in the metal base; change in the form of graphite inclusions of cast iron from lamellar to nest-shaped (rosette), spherical (globules); increase in strength up to $35-50 \%$.
\end{abstract}

Keywords- silica; carbon; modification; grey iron; microstructure; modifier

\section{INTRODUCTION}

It is always topical to increase the physico-mechanical properties of cast parts responsible for safe operation of the equipment under increased loads. For this purpose, castings from gray iron only of high grades are increasingly required in production. Improvement of the casting and mechanical properties of castings of gray iron and steels is impossible without effective alloying and modifying cast iron and steels that can eliminate bleaching in cast iron castings, grind grain, eliminate transcrystallization, segregation, shrinkage and other undesirable phenomena in steels [1-6]. It is seen from analysis of works on the modification [1-6] that silicon is the most effective graphitizer and an indispensable component of practically all modifiers used in industry. Additives of other elements, such as $\mathrm{Ca}, \mathrm{Ba}, \mathrm{Mg}, \mathrm{Sr}$, etc., are used only to enhance the effect of modifying and increasing the survivability of modifiers [3-5]. Given the wide variety of methods for smelting cast iron and steel, nomenclature of castings by weight and their thickness variation, and to meet the requirements of modern production, it is necessary to create advanced technologies based on a new generation of complex modifiers, deoxidizing mixtures, refining additives that significantly exceed the efficiency of existing ones with substantially less consumption. This work is devoted to the solution of this problem.

Aim of this work is to study the effect of nanoadditives with increased chemical activity of carbon and silicon on phase formation during solidification of cast iron GI10,15 by quenching from the liquid state; Brief description of nano modifiers. This ultradisperse material was obtained by us in the process of chemical-thermal treatment of metallurgical waste. [7] The first composition of the modifier (composition 1) consisted of a concentrate of carbon nanotubes and represented a black powder, odorless, chemically non-toxic. The studied mixture modifier consists of graphite microparticles and multi-walled carbon nanotubes. The most active component is nanotubes, they are long cylindrical 
structures with a diameter of 10 nanometers and a length of up to $0.5 \mathrm{~mm}$.

Fig.1. Characteristics: - Chemical formula, composition: $\mathrm{C}$ - 99\%, $\mathrm{SiC}-1 \%$; - Concentration of nanotubes: stable: $20 \%$,
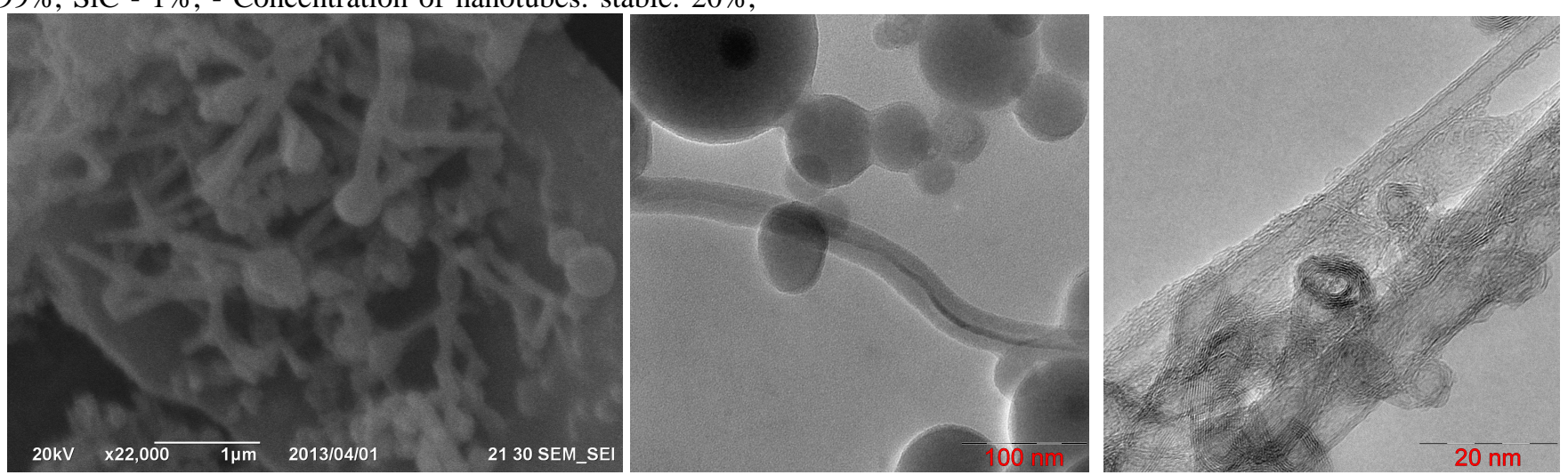

Fig. 1. Electron-microscopic photo modifier made of carbon nanotubes, obtained with the help of transmission electron microscopy
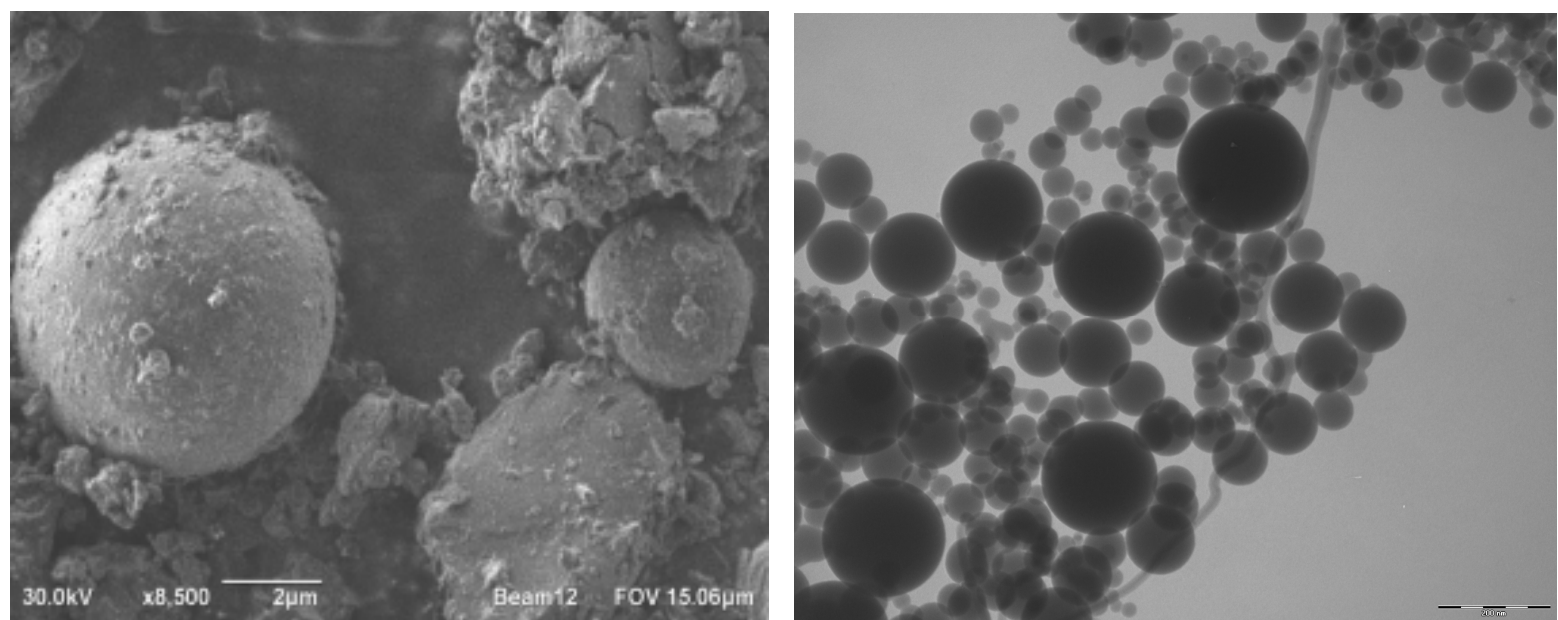

Fig.2. Electron microscopic photos of the modifier that consists of a silicon nanoparticle.

The second composition of the modifier (composition 2) consisted of silicon dioxide nanogranules (89-99\%) and amorphous carbon, and they represent free-flowing powder of white color and have a very large specific surface area. The material has an unsaturated structure of an alkyl type with different types of bonds. Non-toxic, odorless, non-polluting white powder with stable chemical properties. Nano-granules of silicon dioxide significantly change the properties of systems that contain ordinary micron silicon oxide (Fig. 2). Characteristics: - Chemical formula, composition: $\mathrm{SiO} 2$ 99\%, SiC $1 \%$ - Molecular weight: $60.1 \mathrm{~g} / \mathrm{mole}$. Melting point: 1750 C- Boiling point: $2355 \mathrm{C}$ - Density: $0.5 \mathrm{~g} / \mathrm{cm}^{3}$ - Heat capacity: $937 \mathrm{KJ} / \mathrm{g}{ }^{\circ} \mathrm{C}$ - Thermal resistance: $1.3 \mathrm{~W} / \mathrm{m} \mathrm{K}$

The third composition (composition 3) consists of a mixture: the first and second composition in proportion $(30 \%$ to $70 \%$ ) (Fig. 3).
$60 \%$, 90\%; - Melting point: $3527{ }^{\circ} \mathrm{C}$; - Boiling point: $4300{ }^{\circ} \mathrm{C}$; - Density $0,4 \mathrm{~g} / \mathrm{cm}^{3}$; - Heat capacity $8,5 \mathrm{~J} / \mathrm{g}{ }^{\circ} \mathrm{C}$ - Thermal resistance: $1,59 \mathrm{~W} / \mathrm{m} \mathrm{K}$ 


\section{MATERIALS AND METHODS OF RESEARCH}

Experiments to determine the effect of the components of the mixture modifier on the modification process were carried out with gray iron of the grade GI, 10-25. These grades of gray iron were melted in an induction furnace of grade IST016. Modification of the cast iron was carried out at a temperature $(1430+-1450){ }^{\circ} \mathrm{C}$, measured by a thermocouple VR-5/20. To modify the gray iron, modifiers, that have the chemical composition mentioned above, were used. Three types of modifier were used: amorphous carbon-nanotubes (20\%) (composition 1), nanoscale silicas (composition 2) and amorphous carbon, nanotubes $(20 \%)$, silicon beads (composition 3). Each modifier was treated with two melts. Cylindrical samples with a diameter of $16-25 \mathrm{~mm}$ were cast into dry sand molds, the cooling rate was $4.3{ }^{\circ} \mathrm{C} / \mathrm{sec}$. The effect of the modification was evaluated on the basis of the results of metallographic studies and analysis of the mechanical properties of materials. The microstructure of cast irons after mechanical tests was investigated on longitudinal and transverse sections, in etched and unetched states [8,9]. The initial microstructure of the cast iron was evaluated according to GOST 3443-87.

Results of experiments and discussion. The gray iron was melted in the standard melting regime according to the current technological instructions. The analysis of the strength characteristics showed that the temporary resistance to rupture of the experimental modified cast iron sample was $270 \mathrm{MPa}$, which is significantly higher in comparison with the witness sample that has a temporary resistance of $210 \mathrm{MPa}$. At the next stage of the test, the influence of the modifier composition on the mechanical properties of gray iron GI15 was evaluated. For this, several melts with different weighed modifier (composition 1) were carried out. The results are shown in Table 1. Comparing the three series of experiments of the sample of gray iron GI15 with different degrees of modification, it is seen that the mechanical properties increase and correspond to GOST 1412-85 in the grade GI20 and GI25. It can be stated that the use of the modifier of composition 1, which has $20 \%$ of nanotubes in its composition, significantly increases the mechanical properties of gray iron of GI10,15 type.

TABLE I. TEST RESULTS OF MODIFIER OF COMPOSITION 1

\begin{tabular}{|l|c|c|c|c|l|}
\hline sample & \multicolumn{2}{|l|}{ Weight in the ladle, } & $\begin{array}{l}\text { Hardness } \\
\text { MPa }\end{array}$ & $\begin{array}{l}\text { Temporal } \\
\text { resistance } \\
\text { HB }\end{array}$ & $\begin{array}{l}\text { Grade } \\
\text { (GOST } \\
1412-85)\end{array}$ \\
\cline { 2 - 5 } & $120 \mathrm{~kg}$ & modifier & & $168-178$ & GI10, GI15 \\
\hline $\begin{array}{l}\text { origina } \\
1\end{array}$ & - & - & $185-210$ & 240 & GI25 \\
\hline №1 & & $120 \mathrm{~g}$ & 263 & 270 & GI25 \\
\hline №2 & & $77 \mathrm{~g}$ & 260 & 200 & GI20 \\
\hline №3 & & $46 \mathrm{~g}$ & 233 & & \\
\hline
\end{tabular}

A series of experiments for the melting of cast iron GI15, according to the sandwich-type scheme of the process with a modifier (composition 1), which did not reveal any significant differences in the mechanical properties of the modified samples, depending on the mode of administration. This fact contradicts the stable opinion of the advantages of the sandwich-type modification process [4,10-14]. The next step in the study was the evaluation of the modifier of composition 2. Several melts with different concentrations of the modifier, composition 2, were carried out for this. The results are shown in Table 2. The evaluation of the modifier (composition 2) showed a significant increase in the mechanical properties of gray iron, grade GI10,15,25. At the same time, it is necessary to note changes in the chemical composition of the modified samples, in all samples modified with composition 2, an increase in the content of silicon, phosphorus and sulfur was observed. Apparently, this is due to the fact that sulfur and phosphorus as non-removed salts are present in the modifier (composition 2.). To clarify this assumption, it is necessary to conduct additional studies of the modifier of composition 2, with a different degree of purification from contaminants.

TABLE II. TEST RESULTS OF MODIFIER OF COMPOSITION 2

\begin{tabular}{|c|c|c|c|c|c|}
\hline \multirow[t]{2}{*}{ Sample } & \multicolumn{2}{|c|}{ Weight in the ladle, } & \multirow{2}{*}{$\begin{array}{l}\text { Hardness } \\
, \mathrm{MPa}\end{array}$} & \multirow{2}{*}{$\begin{array}{l}\text { Temporal } \\
\text { resistance } \\
\text {, HB }\end{array}$} & \multirow{2}{*}{$\begin{array}{l}\text { Grade } \\
\text { (GOST } \\
1412-85)\end{array}$} \\
\hline & $120 \mathrm{~kg}$ & modifier & & & \\
\hline $\begin{array}{l}\text { Original } \\
\text { casting of } \\
\text { modifier }\end{array}$ & - & - & $185-210$ & $168-180$ & GI10, GI15 \\
\hline №1 & & $120 \mathrm{~g}$ & 220 & 240 & GI25 \\
\hline №2 & & $77 \mathrm{~g}$ & 210 & 270 & GI25 \\
\hline №3 & & $46 \mathrm{~g}$ & 190 & 200 & GI20 \\
\hline $\begin{array}{l}\text { Sandwich } \\
\text { process }\end{array}$ & & & & & \\
\hline Original & - & - & $185-210$ & $168-180$ & GI10,GI15 \\
\hline №1 & & $120 \mathrm{~g}$ & 363 & 240 & GI25 \\
\hline №2 & & $77 \mathrm{~g}$ & 360 & 270 & GI25 \\
\hline №3 & & $46 \mathrm{~g}$ & 190 & 200 & GI20 \\
\hline $\begin{array}{l}\text { Original } \\
\text { casting of } \\
\text { modifier }\end{array}$ & - & - & $210-230$ & 240 & GI25 \\
\hline №1 & & $120 \mathrm{~g}$ & 363 & 310 & GI30 \\
\hline №2 & & $77 \mathrm{~g}$ & 260 & 290 & GI30 \\
\hline №3 & & $46 \mathrm{~g}$ & 210 & 250 & GI25 \\
\hline
\end{tabular}

Further, the modifier of composition 3 was evaluated. For this, as well as in the experiments described above, several melts with different concentrations of the modifier of composition 3 were carried out. Modification was carried out by pouring the melt onto the modifier in the ladle. The results are presented in Table 3. 
TABLE III. TEST RESULTS OF MODIFIER OF COMPOSITION 3

\begin{tabular}{|c|c|c|c|c|c|}
\hline \multirow[t]{2}{*}{ Sample } & \multicolumn{2}{|c|}{$\begin{array}{l}\text { Weight in the } \\
\text { ladle, }\end{array}$} & \multirow[t]{2}{*}{$\begin{array}{l}\text { Hardness } \\
\mathrm{MPa}\end{array}$} & \multirow{2}{*}{$\begin{array}{l}\text { Temporal } \\
\text { resistance, } \\
\mathrm{HB}\end{array}$} & \multirow{2}{*}{ 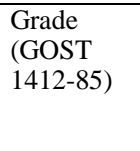 } \\
\hline & $\begin{array}{l}120 \\
\mathrm{~kg}\end{array}$ & modifier & & & \\
\hline Original & - & - & $185-210$ & $168-178$ & GI10, GI15 \\
\hline №1 & & $120 \mathrm{~g}$ & 263 & 310 & GI30 \\
\hline №2 & & $77 \mathrm{~g}$ & 260 & 270 & GI30 \\
\hline №3 & & $46 \mathrm{~g}$ & 233 & 240 & GI25 \\
\hline
\end{tabular}

Surface examination of the samples with the help of scanning electron microscopy showed significant differences in the structure of the metal surface. All the materials studied have the structure of gray iron on a ferrite-pearlitic basis with graphite of a laminar rectilinear form of the type PGf1, in unmodified samples. Fig. 4 (a, b). Modified samples have the form of inclusions of graphite of the type PGf4 nest-shaped, vortical shape Fig. 5 (a,b).

The content of ferrite is $\sim 8 \%$ according to GOST F8. In the control alloy, graphite PGr1 is evenly distributed over the volume of the material, the content of ferrite is greater and is $45 \%$, according to GOST-F55. The average length of inclusions is $\sim 500 \mu \mathrm{m}$, according to GOST-PGD750. The distance between the cementite plates is $\sim 1-5 \mu \mathrm{m}$. In modified samples, the graphite distribution has a less uniform structure. The average length of the graphite plates is $100 \mu \mathrm{m}$, PGD90. However, there are areas in which graphite inclusions have a rosette distribution and are about 30-50 $\mu \mathrm{m}$ long, PGD25. The dispersion of the ferritic-cementite mixture plates in the modified samples is approximately the same.

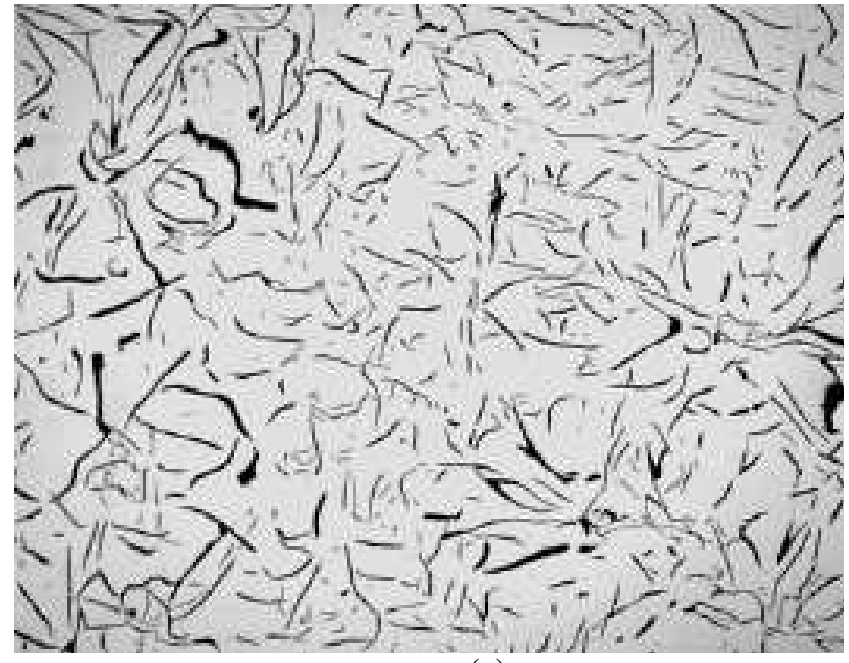

(a)

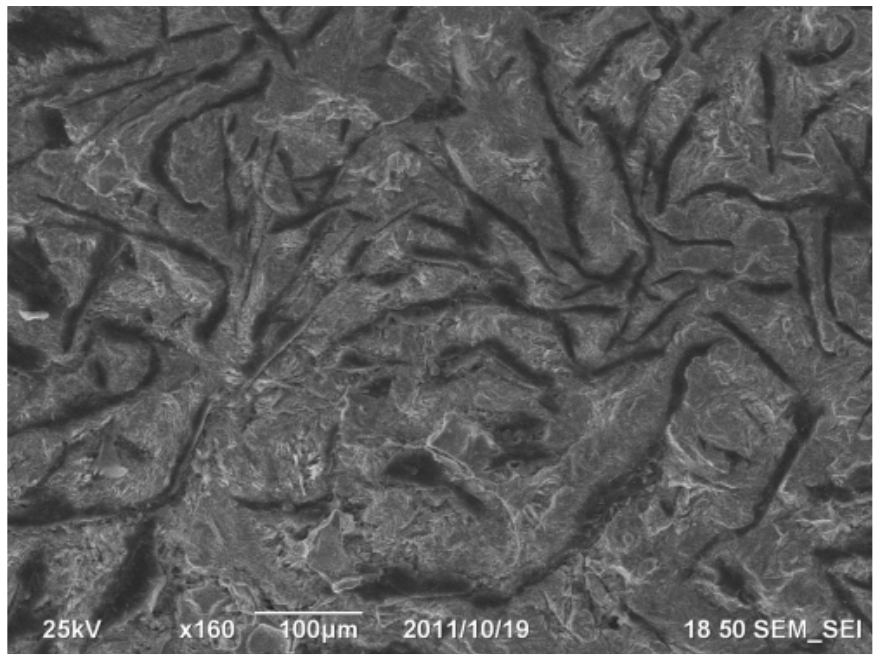

(b)

Fig. 4. The initial structure of gray iron grade GI15 with graphite laminar rectilinear PGF1: a-optical microscope; b-scanning electron microscope

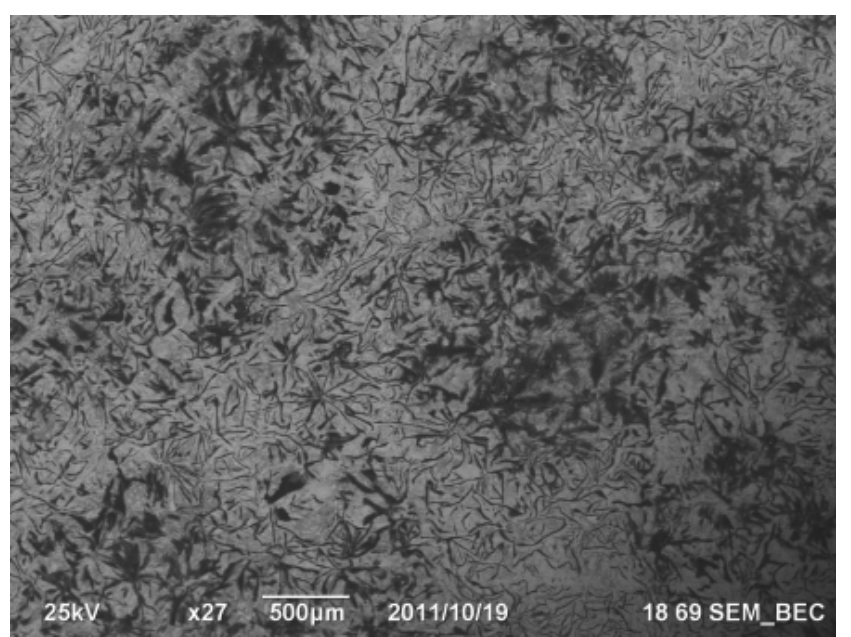

(a)

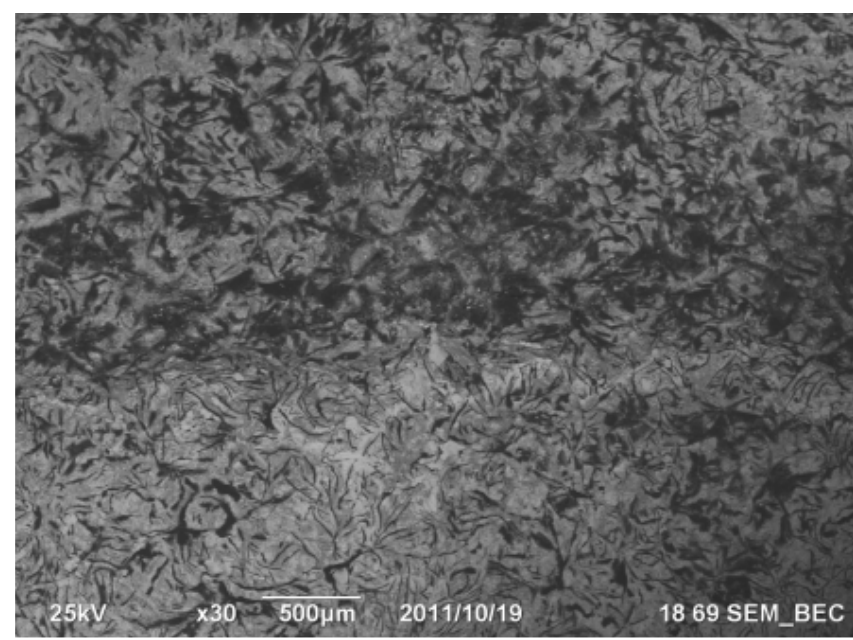

(b)

Fig.5. The structure of cast iron GI15 after being modified with a composition 1 (a) and composition 3 (b) (shape of graphite has changed to a nest-shaped one, PGf4) 
Almost all the studied alloys consist of phosphide eutectic. The eutectic inclusions are uniformly distributed when modified with composition 1 ; the average area of inclusions is $500 \mu^{2}$, FED400. When modified with composition 2, the eutectic inclusions are distributed non-uniformly, the average inclusions area does not exceed $200 \mathrm{~mm}^{2}$, FED250. Samples, modified with composition 3 , showed no significant changes in the shape and distribution of the phosphide eutectic. In the studied modified samples, graphite inclusions of two types are observed.

In the greater part of the volume there are evenly distributed inclusions of the vortex form (rosetted) PGr7, their length is $\sim 100-150 \mu \mathrm{m}$. While in unmodified samples there are colonies of lamellar graphite of the type PGr3. The second type of graphite represents small plates with a length of up to 10-30 $\mu \mathrm{m}$, located in the interdendritic space. As a result of modifying cast iron GI15 with composition 3, the dispersity of the structural constituents of the lamellar perlite increases.

\section{CONCLUSION}

The performed experiments and the analysis of the obtained results of the graphitizing ability of the modifier with nanostructures showed that its introduction into the melt of gray iron makes it possible to reduce the release of free ferrite in the microstructure of cast iron up to 5-8\% with the invariable hardness of HB 207-217, and also contributes to obtaining the most favorable morphology of graphite - PGr1 (growth of larger plates of graphite of the same size) and a more even distribution over the volume of the metal matrix. The conducted studies of microstructures after mechanical tests of samples of cast iron GI30, modified with composition 2 , showed the presence of inclusions of globular graphite. The introduction of small amounts of a modifier with nano-sized structures during the teeming leads to: an increase in the content of perlite in the metal base; change in the form of graphite inclusions of cast iron from lamellar to nest-shaped (rosette), spherical (globules); increase in strength up to 35$50 \%$.

\section{References}

[1] K.P. Bunin, Yu.N. Taran. Stroenie chuguna. Moskow: Metallurgiya, $1972,160 \mathrm{p}$.

[2] A.A. Gorshkov, "O mekhanizme obrazovaniya sharovidnogo grafita," Litejnoe proizvodstvo, vol. 3, pp. 17-21, 1995.

[3] N.G. Girshovich, Spravochnik po chugunnomu lit'yu, M.-L.: Mashinostroenie, 1978, $758 \mathrm{p}$.

[4] S.V. Davydov, A.G. Panov, "Tendenciya razvitiya modifikatorov dlya chuguna i stali," Zagotovitel'noe proizvodstvo v mashinostroenii, vol. 1, pp. 3-12, 2007.

[5] D.A Boldyrev, A.V. Chajkin, "Novye smesevye modifikatory dlya inokuliruyushchej obrabotki chugunov," Litejshchik Rossii, vol. 3, pp. 32-36, 2007.

[6] T. Skaland, T. Grong, T. Grong, A Model for the Graphite Formation in Ductile Cast Iron: Part I. Inoculation Mechanisms, Met. Trans A, vol. A24, pp 2321-2345, 1993.

[7] V.V. Kondrat'ev, N.A. Ivanov, A.E. Balanovskij, N.N. Ivanchik and A.I. Karlina, "Uluchshenie svojstv serogo chuguna kremnij dioksid i uglerodnymi nanostrukturami," ZHurnal Sibirskogo federal'nogo universiteta. Seriya: Tekhnika i tekhnologii, vol. 5, pp. 671-685, 2016.

[8] I.A. Rybenko, O.I. Nokhrina, I.D. Rozhikhina, M.A. Golodova and V.P. Tsymbal, "Resource-saving direct alloying of steel," Steel in Translation, vol. 47(2), pp. 85-90, 2017.

[9] I.D. Rozhikhina, O.I. Nokhrina, V.I. Dmitrienko and M.A. Platonov, "Modification of steel with barium and strontium," Steel in Translation, T. 45, vol. 12, pp. 908-912, 2015.

[10] O.I. Nokhrina, I.D. Rozhikhina, I.E. Khodosov and I.E. Proshunin, "Production and use of concentrates from polymetallic manganese ore," Steel in Translation, T. 45, vol. 5, pp. 295-300, 2015.

[11] O.I. Nokhrina, I.D. Rozhikhina, V.I. Dmitrienko, M.A. Golodova and Y.A. Osipova, "Microalloying of steel with vanadium and nitrogen," Steel in Translation, T. 44, vol. 10, pp. 715-718, 2015.

[12] V.I. Dmitrienko, O.I. Nokhrina, I.D. Rozhikhina, A.V. Dmitrienko, "Phase transformations and metallurgical properties of barium-strontium modifier," Steel in Translation, T. 44, vol. 6, pp. 411-412, 2014.

[13] V.I. Dmitrienko, I.D. Rozhikhina, O.I. Nokhrina, R.S. Aizatulov and M.A. Platonov, "Reduction of barium and strontium in the ladle treatment of steel," Steel in Translation, T. 42, vol. 4, pp. 305-307, 2012.

[14] O.I. Nohrina, I.D. Rozhihina, "Ispol'zovanie pyli i othodov frakcionirovaniya ferrosiliciya dlya raskisleniya i legirovaniya stali $\mathrm{v}$ kovshe," Izvestiya vysshih uchebnyh zavedenij. CHernaya metallurgiya, vol. 10, p. 49, 2003 